\title{
Renal Coloboma Syndrome
}

National Cancer Institute

\section{Source}

National Cancer Institute. Renal Coloboma Syndrome. NCI Thesaurus. Code C123230.

A genetic disorder caused by PAX2 gene mutations that is characterized by renal

hypoplasia and a spectrum of congenital anomalies of the eye and urinary tract. 